PROCEDIA

Studi Kasus dan Intervensi Psikologi

ISSN:2302-1462; e-ISSN: 2722-7669

Volume 8(4) 153-160, Desember 2020

DOI: $10.22219 /$ procedia.v8i4.14786

\title{
Konseling pendekatan kognitif untuk mengatasi kesepian
}

Sururun Marfuah, Universitas Muhammadiyah Malang, Malang, Indonesia

Korespondonesi:

Sururun Marfuah, email: sururunmarfuah11@gmail.com

Riwayat artikel
Naskah diterima:
27/09/2020

Revisi diterima:

$15 / 10 / 2020$

Naskah disetujui: $04 / 12 / 2020$

\begin{abstract}
Abstrak
Individu yang masuk dalam masa dewasa awal dituntut untuk mengembangkan hubungan sosial yang baik. Kesulitan dalam berinteraksi sosial pada dewasa awal dipengaruhi oleh pengalaman tidak menyenangkan di masa lalu yang memunculkan rasa tidak percaya terhadap lingkungan. Kesepian adalah bentuk hubungan sosial yang tidak sesuai dari apa yang diinginkan atau dicapai, termasuk perasaan gelisah, tertekan dan persepsi kurangnya hubungan sosial pada diri seseorang. Tingkat kesepian yang beragam bisa diintervensi dengan metode yang beragam pula. Konseling kognitif terbukti efektif dilakukan pada individu kesepian yang masih mampu melakukan aktivitas keseharian dan memiliki dukungan sosial yang baik. Konseling kognitif dalam penelitian ini dilakukan sebanyak 5 sesi. Skala kesepian yang digunakan adalah UCLA loneliness scale. Hasil penelitian menunjukkan bahwa subjek mengalami perubahan kategori tingkat kesepian dari tinggi menjadi sedang setelah dilakukan konseling kognitif.

Kata kunci: Kesepian, hubungan sosial, konseling kognitif.
\end{abstract}

\section{Latar Belakang}

Dewasa awal merupakan masa individu memasuki usia 18 - 25 tahun. Tugas-tugas perkembangan dewasa awal mulai bertambah, terutama pada hal hubungan sosial. Menurut Hurlock (2009), dewasa awal harus mampu bergabung dalam suatu kelompok sosial dan berinteraksi dengan baik untuk bekal dalam tugas yang lebih berat yaitu menemukan pasangan hidup dan membina rumah tangga. Dewasa awal harus mencari jalannya sendiri dalam menjalin persahabatan baru dan memantapkan identitas mereka lewat upaya sendiri. Kesulitan dalam berinteraksi sosial pada dewasa awal dapat dipengaruhi oleh pengalaman tidak menyenangkan di masa lalu yang memunculkan rasa tidak percaya terhadap lingkungan.

Dalam menjalani kehidupan, individu dihadapkan pada beberapa peralihan siklus kehidupan. Hal ini termasuk memasuki atau menyelesaikan pendidikan, terlepas dari orangtua, menikah, 
memiliki karir baru, menjadi orangtua, ditinggalkan oleh anak hingga pensiun. Terdapat beragam permasalahan yang muncul ketika melewati masa peralihan ini. Hubungan dan interaksi sosial yang tidak terbangun dengan baik memunculkan beberapa persepsi dari individu, salah satunya kesepian.

Kesepian didefinisikan sebagai perasaan yang tidak menyenangkan dan merangsang kecemasan subjektif sebagai hasil dari hubungan sosial yang kurang memadai (Tiikkainen \& Heikkinen, 2005). Definisi lainnya menyebutkan bahwa kesepian merupakan bentuk hubungan sosial yang tidak sesuai dari apa yang diinginkan atau dicapai, termasuk perasaan gelisah, tertekan dan persepsi kurangnya hubungan sosial pada diri seseorang. Terdapat tiga aspek seseorang mengalami kesepian yaitu trait loneliness merupakan kepribadian seseorang yang kurang memiliki kepercayaan dan ketakutan terhadap orang asing. Social desirability loneliness yaitu tidak mendapat kehidupan sosial yang diinginkan pada kehidupan dan lingkungannya. Depression loneliness yaitu merasakan sebuah kegagalan yang membuat sedih, murung, tidak bersemangat dan merasa tidak berharga (Lou et al., 2012).

Remaja yang merasakan kesepian rentan mengalami kesejahteraan diri yang rendah, masalah penyesuaian diri termasuk harga diri yang rendah, tingginya kesempatan untuk keluar dari sekolah, tindak kriminal, kecemasan tinggi, gejala depresi dan memiliki ide/pikiran bunuh diri. Selain itu, kesepian juga berkaitan dengan masalah fisik seperti kualitas tidur yang buruk dan peningkatan frekuensi dalam mengunjungi dokter. Sebagai tambahan, kesepian juga dihubungkan dengan faktor-faktor intrapersonal seperti introversi, perasaan malu dan pengungkapan diri yang rendah. Sedangkan faktor interpersonal seperti rasa tidak aman, gaya kelekatan, penolakan teman sebaya penipuan dan rendahnya kualitas persahabatan (Maes, 2016).

Berbagai akibat yang akan dialami akibat perasaan kesepian yang berkepanjangan, bisa diatasi dengan teknik intervensi psikologi yang beragam sesuai kebutuhan dari individu. Dalam kasus ini, dari ketiga aspek yang membentuk rasa kesepian, aspek yang paling menonjol adalah social desirability dimana subjek tidak mendapatkan kehidupan sosial yang diinginkan sehingga membuat subjek menarik diri dari lingkungan dan kurang mampu membentuk hubungan sosial yang baru. Hal ini terjadi karena pemikiran dan asumsi yang dibentuk oleh subjek, cenderung kearah negatif. Sehingga intervensi yang bisa dilakukan adalah konseling dengan pendekatan kognitif. Berdasarkan penelitian oleh Kemala (2017), kegiatan konseling efektif dan dibutuhkan untuk mengatasi masalah kesepian pada remaja.

\section{Metode Asesmen}

Asesmen yang telah dilakukan untuk penegakan diagnosa melalui serangkaian metode antara lain wawancara dan tes psikologi. Wawancara dilakukan terhadap subjek dan teman dekat untuk memperoleh informasi lebih mendalam tentang riwayat permasalahan yang dikeluhkan subjek. Kemudian juga dilakukan observasi untuk mendukung wawancara. Tujuannya adalah untuk mengetahui perilaku-perilaku yang muncul yang bisa mengarah pada suatu gangguan atau masalah. Tes psikologi menggunakan tes intelegensi menggunakan Culture Fair Intelligence Test (CFIT) untuk mengetahui potensi intelektual guna memprediksi sejauh mana pemahaman subjek terhadap intervensi yang akan diberikan. Sedangkan tes kepribadian menggunakan grafis dan wartegg untuk mengungkap kecenderungan kepribadian dan konsep diri subjek secara lebih mendalam, serta mengungkap dinamika kepribadian subjek dalam hubungan interpersonal, dorongan emosi dan konflik pribadi yang dominan dalam diri subjek. Instrumen psikologi tambahan yaitu UCLA loneliness scale untuk mengukur seberapa tinggi tingkat kesepian yang dialami oleh subjek. Skala ini juga bertujuan untuk mengukur perubahan subjek sebelum dan sesudah diberikan intervensi. 


\section{Presentasi Kasus}

Subjek merupakan perempuan berusia 21 tahun yang sedang menempuh semester 7 di salah satu universitas di Malang. Subjek mengeluhkan bahwa dirinya sering mendadak merasa sedih dan menangis tanpa sebab selama setahun terakhir. Terkadang subjek memukul-mukul dinding sebagai pelampiasan kebingungannya. Subjek merupakan anak pertama dari 3 bersaudara dan memiliki hubungan antar keluarga yang harmonis dan subjek sendiri sangat bergantung pada keluarganya. Subjek merasakan dukungan yang nyata dari keluarganya khususnya ibu ketika melakukan sesuatu. Namun, ayahnya yang bekerja sebagai TNI jarang memiliki waktu luang untuk keluarga sehingga subjek sangat ingin ayahnya segera pensiun dan banyak istirahat, mengingat kondisi kesehatan ayahnya yang semakin menurun karena diabetes. Sejak kecil, subjek terbiasa diskusi dengan keluarga ketika akan memutuskan suatu hal termasuk keputusannya untuk merantau ke Jawa. Subjek merasa bahwa keputusan ini adalah keputusan paling besar dan paling menyedihkan yang pernah subjek pilih.

Selain itu, subjek menyatakan bahwa ia merasa menjadi pribadi yang tergantung pada keluarga dan tidak bisa mandiri. Oleh karena itu, subjek memaksakan diri untuk merantau ke Jawa demi menjadi contoh yang baik bagi kedua adik perempuannya. Subjek ingin menjadi seseorang yang sukses dan bisa menjadi kebanggaan keluarga. Namun, dengan kepribadian subjek yang sangat dekat dengan keluarga, di awal masa kuliah, membutuhkan waktu lama untuk bisa terbiasa jauh dari keluarga. Saat itu, subjek sering merasa sedih dan tiba-tiba menangis ketika mengingat keluarganya.

Beradasarkan hasil asesmen ditemukan bahwa subjek memiliki tingkat kecerdasan yang berada di kategori rata-rata (IQ 96) dan kurang mampu dalam melakukan hubungan sosial. Subjek akan mempertimbangkan beberapa kemungkinan ketika berusaha berinteraksi dengan orang baru, seperti permasalahan apakah mereka orang yang baik atau apakah mereka akan antusias meresponnya. Hal ini terjadi karena subjek pernah mengalami bullying secara verbal yang mengarah pada body shaming akibat asal usul dari Papua. Mulai saat itu, subjek berhati-hati dalam berkata-kata khususnya jika berada di lingkungan baru. Subjek mulai bisa menyesuaikan diri ketika menginjak semester ketiga, didukung kegiatan perkuliahan yang sudah mulai padat. Subjek mengaku memiliki dua orang sahabat. Pertama, sahabat dari SMA yang juga merantau di Jakarta dan yang kedua adalah teman sekelasnya. Kemudian, secara hampir bersamaan, kedua sahabat subjek tersebut memiliki pasangan yang membuat mereka kurang memprioritaskan subjek. Subjek pernah menegur untuk jangan terlalu bergantung pada pasangan, namun sahabatnya justru menertawakan subjek yang tidak memiliki pasangan. Subjek sadar bahwa itu hanya candaan, namun ia merasa sakit hati. Subjek memaknainya dengan bertanya pada diri sendiri bahwa apakah salah jika tidak memiliki pacar.

Subjek terkadang iri dan ingin memiliki pacar juga, namun subjek menyadari bahwa untuk sekedar menjalin pertemanan saja, ia sudah merasa kesulitan. Subjek pernah satu kali menjalin hubungan romantis ketika kelas 3 SMP, namun subjek mengaku tidak tahan karena terlalu diatur dan sering dilarang dalam melakukan sesuatu. Hal ini memperkuat persepsi subjek bahwa dirinya memang sulit dalam menjalin hubungan sosial dengan baik. Akibat hal ini, subjek menjadi enggan untuk menghubungi sahabatnya dan mulai mengurangi intensitas untuk menghubungi mereka. Subjek merasa mampu melewati berbagai situasi sendiri ditambah dengan kegiatan kampus yang semakin padat dan melelahkan. Akan tetapi, situasi menyibukkan yang dialami subjek membuatnya lebih sensitif sehingga tanpa disadari, ia lebih banyak menyendiri. Kesendiriannya mendorong subjek untuk memikirkan berbagai hal yang tidak seharusnya menjadi pikirannya saat itu sehingga cukup sering merasa sedih dan menangis tiba-tiba tanpa ada alasan atau sebab yang jelas.

Berdasarkan pemaparan tersebut, subjek mengalami kesepian karena memenuhi tiga aspek kesepian menurut Russell yaitu (a) trait loneliness dimana subjek merasa kurang memiliki 
kepercayaan dan ketakutan terhadap lingkungan asing, (b) desirability loneliness dimana subjek tidak mendapatkan kehidupan sosial yang diinginkannya dan, (c) depression loneliness dimana kegagalan dalam hubungan sosial yang dirasakan subjek membuat sedih, murung, tidak bersemangat dan tidak berharga (Lou et al., 2012). Hal ini didukung dengan skor UCLA loneliness scale yang menunjukkan tingkat kesepian subjek berada pada kategori tinggi.

Masalah yang mengikuti rasa kesepian yang berkepanjangan, termasuk masalah penyesuaian diri, rasa malu, pengungkapan diri yang rendah dan rendahnya kualitas persahabatan. Masalah-masalah ini bisa diatasi dengan teknik intervensi psikologi yang beragam sesuai kebutuhan dari individu. Dalam kasus ini, dari ketiga aspek yang membentuk rasa kesepian, aspek yang paling menonjol adalah social desirability dimana subjek tidak mendapatkan kehidupan sosial yang diinginkan sehingga membuat subjek menarik diri dari lingkungan dan kurang mampu membentuk hubungan sosial yang baru. Hal ini terjadi karena pemikiran dan asumsi yang dibentuk oleh subjek, cenderung kearah negatif. Oleh karena itu, intervensi yang bisa dilakukan adalah konseling dengan pendekatan kogntif.

Konseling kognitif adalah intervensi psikologi yang mengarahkan dan membantu subjek untuk merubah pemikiran-pemikiran negatif terkait kejadian masa lalu dan lingkungannya menjadi lebih positif. Selain itu, subjek akan dibiasakan untuk lebih terbuka dan berani melakukan hubungan sosial yang baru dengan baik.

\section{Diagnosis dan Prognosis}

Berdasarkan hasil asesmen, subjek termasuk memiliki kriteria dari V15.89 (Z91.89) Other personal risk factors dengan faktor resiko pemikiran negatif tentang masa lalu dan lingkungan yang memfokuskan permasalahan pada kesepian. Tingkat keberfungsian subjek diukur menggunakan WHODAS, termasuk dalam kategori sedang.

Adapun prognosis subjek berdasarkan kriteria untuk mengukur tingkat kesembuhan diketahui bahwa subjek memiliki prognosis yang baik. Hal ini karena subjek berada pada tingkat keparahan yang rendah, sering melakukan usaha untuk menjadi lebih baik, meskipun belum pernah ditangani secara profesional dan memiliki motivasi internal yang baik.

\section{Intervensi}

Intervensi yang dilakukan adalah konseling dengan pendekatan kognitif. Target dari intervensi ini adalah untuk mengubah pemikiran-pemikiran negatif yang ada pada subjek sehingga subjek mampu menjalani kesehariannya dengan baik. Berikut adalah pemaparan dari sesi-sesi konseling yang telah dilakukan.

Sesi 1: Perkenalan dan kontrak Sesi ini merupakan tahap permulaan dimana terapis telah menyimpulkan keadaan subjek berdasarkan asesmen yang telah dijelaskan. Terapis menjelaskan bahwa diperlukan tindak lanjut terhadap kondisi subjek agar subjek mampu menjadi individu yang lebih baik. Terapis meminta kesediaan subjek untuk mengikuti intervensi yang akan dilakukan selama beberapa pertemuan dan menjelaskan tujuan dari intervensi.

Sesi 2: Identifikasi masalah dan pengembangan masalah Dalam sesi ini, subjek mengungkapkan seluruh permasalahan yang dialaminya dan asumsi subjek dalam menghadapi permasalahan tersebut. Hal ini bisa terwakili dengan bagaimana subjek mengambil sikap dan perilaku dalam menghadapi kejadian tersebut.

Sesi 3: Pengembangan dan penyusunan solusi Dalam sesi ini, subjek diarahkan untuk mencari kemampuan diri yang telah ada pada dirinya, membebaskan dirinya dan tidak memperhatikan kondisi yang tidak nyaman kemudian lebih berfokus pada hal lain yang lebih positif dan bermanfaat. Subjek mengaku target utama dalam hidup ini adalah menjadi seseorang yang mandiri dan tidak bergantung pada keluarga maupun orang lain. Namun, kenyataannya 
subjek selalu merasa hampa dan merasa tidak optimal ketika mengerjakan tugas-tugasnya jika tidak ada orang lain di sekitarnya. Sesi ini meminta subjek fokus pada keinginan untuk menjadi pribadi yang mandiri dan menyebutkan kelebihan-kelebihan yang dimilikinya. Hal ini agar subjek menemukan insight bahwa solusinya dapat ditemukan. Terapis memberikan beberapa pengertian, yang pertama menjadi mandiri bukan berarti tidak membutuhkan lingkungan sosial. Menarik diri bukan perilaku yang tepat untuk dilakukan. Kedua, dukungan dari lingkungan tidak selalu terlihat secara fisik. Namun, subjek bisa merasakannya meskipun tidak terlihat atau berada jauh dari posisi subjek sekarang.

Sesi 4: Identifikasi pemikiran negatif dan mind switching Dalam sesi ini, subjek melakukan identifikasi pemikiran-pemikiran negatif yang selama ini ada di pikiran subjek, termasuk kejadian di masa lalu yang membuat subjek menarik diri dari lingkungan. Kemudian, subjek diminta untuk mengubah pemikiran negatif yang ada menjadi pemikiran yang lebih positif.

Sesi 5: Tugas rumah Dalam sesi ini, subjek diberikan tugas rumah yaitu memberanikan diri untuk membangun interaksi di sekitar lingkungannya. Interaksi yang dibangun adalah dengan menyapa teman kos, menanyakan kabar dan menghubungi sahabatnya untuk meminta klarifikasi ketika dia bercanda dan menertawakan subjek. Hal ini untuk membiasakan diri dan membuktikan bahwa persepsi negatif yang selama ini diyakini tidak selalu benar. Persepsi negatif yang dimaksud adalah tidak semua orang mampu menerimanya dengan baik dan bahwa temannya tidak lagi memprioritaskan dirinya sebagai teman setelah memiliki pacar.

Subjek sudah mampu melakukan interaksi kecil dengan lingkungan sekitarnya. Namun, karena sesi intervensi terhalang kegiatan liburan yang membuat subjek sering berkumpul dengan saudaranya sehingga tugas rumah yang diberikan kurang diprioritaskan. Beberapa target terpenuhi, namun ada beberapa yang belum dilaksanakan oleh subjek.

Sesi 6: Evaluasi Evaluasi yang dilakukan adalah hasil dari tugas rumah yang diberikan. Hal yang perlu dievaluasi adalah bagaimana perasaan dan pemikiran subjek setelah melakukan tugas rumah dan perubahan apa yang terdapat pada pemaknaan hidup subjek. Subjek menyadari bahwa kesepian yang dirasakan adalah karena dirinya yang menolak untuk berinteraksi dan sering memainkan asumsi pribadi. Hal berbeda ditunjukkan dimana sekarang subjek mengaku lebih siap untuk membangun interaksi dengan orang lain. Subjek menyadari bahwa dirinya tidak mampu mengendalikan bagaimana respon orang lain, tapi dia mampu mengendalikan responnya sendiri. Terapis memberikan dukungan dengan memotivasi subjek agar terus mempertahankan perilakunya. Target dari pemberian tugas rumah belum sepenuhnya terlaksana karena subjek masih belum siap untuk menanyakan secara langsung apa alasan sahabatnya menertawakannya.

Sesi 7: Follow up Sesi ini dilakukan tiga minggu setelah intervensi, dengan menanyakan keadaan subjek dan mengisi skala UCLA loneliness scale sebagai ukuran perubahan subjek. Subjek mengaku lebih banyak menghabiskan waktu dengan teman-temannya karena kegiatan perkuliahan yang tidak terlalu padat. Pada akhirnya subjek menyadari bahwa selama ini banyak teman yang sebenarnya peduli dengannya namun subjek mengabaikannya dan hanya berfokus pada satu teman yang memiliki kesibukan lain.

\section{Hasil dan Pembahasan}

\section{Hasil}

Berdasarkan hasil intervensi menggunakan konseling kognitif, terdapat perubahan pemikiran menjadi lebih positif antara lain menyadari kelebihan yang dimilikinya, merasa lebih berharga dan mampu mendapatkan kepercayaan diri yang lebih. Hal ini mampu mengurangi rasa kesepian yang dialami subjek. Subjek juga mampu membangun hubungan yang baik dengan 
lingkungan sekitar pada lingkup yang lebih kecil, yaitu teman kosnya. Subjek sudah mengurangi ketergantungan perasaannya pada sahabat lamanya.

Perubahan yang dialami subjek ditunjukkan dengan perbedaan hasil skala UCLA loneliness scale yang telah diisi oleh subjek sebelum dan setelah dilakukan intervensi. Subjek mengalami penurunan tingkat kesepian seperti pada Gambar 1.

Sebelum dilakukan intervensi, subjek memiliki permasalahan kesepian dengan level yang tinggi. Kesepian yang dirasakan subjek adalah hasil dari pengalaman di masa lalu yang membuat subjek memutuskan untuk menarik diri dari lingkungannya dan tidak terbuka ketika ada permasalahan. Perilaku ini berdampak pada kondisi psikologis subjek sehingga menjadi sering menangis tanpa alasan yang jelas. Terapis mengarahkan subjek agar tidak terlalu terfokus pada masalah-masalah yang dihadapinya melainkan pada keinginan subjek untuk segera lulus dan menjadi seseorang yang mandiri. Terapis memberikan beberapa pengertian, yang pertama menjadi mandiri bukan berarti tidak membutuhkan lingkungan sosial. Kedua, dukungan dari lingkungan tidak selalu terlihat secara fisik sehingga subjek seharusnya percaya bahwa dukungan selalu ada meskipun secara fisik, tidak terlihat atau berada jauh dari posisi subjek sekarang.

Perubahan pemikiran negatif menjadi pemikiran positif, memunculkan kesadaran pada diri subjek. Subjek yang mengalami perundungan secara verbal sehingga merasa bahwa orang lain tidak bisa menerima kehadirannya menjadi menyadari bahwa terdapat beberapa orang yang mungkin tidak berpandangan demikian. Berdasarkan hal tersebut, subjek bersedia membangun komunikasi dengan orang lain, dan berusaha mengabaikan ketakutannya terhadap perkataan negatif dari orang lain. Selain itu, subjek merasa tidak diprioritaskan oleh sahabatnya setelah memiliki pacar. Namun, subjek akhirnya menyadari bahwa setiap orang berubah dan prioritas orang berbeda-beda. Subjek berusaha untuk menerima setiap perubahan yang ada di hidupnya. Subjek juga sempat berpikiran bahwa tidak memiliki pacar adalah sebuah kesalahan dan kekurangan. Namun, subjek mampu mengurangi pikiran tersebut dengan mengalihkannya, bahwa yang terpenting adalah belajar membangun hubungan yang baik dengan lingkungan.

Subjek mencoba membangun interaksi dengan lingkungan sekitarnya, paling tidak lingkungan terkecil dimana subjek tinggal. Subjek mampu menanamkan dan mempertahankan prinsip bahwa setiap kejadian pasti memiliki makna masing-masing, terlepas dari baik atau buruknya kejadian tersebut. Subjek mengaku telah menerima respon positif dari temannya sehingga subjek berani mengajak temannya lagi untuk jalan-jalan. Subjek menjadi lebih termotivasi untuk membuka diri pada lingkungannya. Subjek menyadari bahwa tidak semua orang akan menghina atau memandang rendah dirinya.

Pada dasarnya, subjek adalah individu yang mampu berinteraksi baik dengan lingkungan. Pemaknaan negatif pada beberapa pengalaman hidup yang membuatnya menjadi menutup diri bahkan menarik diri dari lingkungan. Subjek perlu mengembalikan kemampuannya tersebut dan mengaplikasikannya pada kehidupan yang sekarang, sehingga semakin banyak interaksi sosial yang dibuat semakin rendah tingkat kesepian yang dirasakannya.

\section{Pembahasan}

Setelah mengikuti intervensi, subjek mampu memaknai setiap kejadian dengan lebih positif. Hal ini membuat intensitas subjek dalam merasakan sedih dan menangis tanpa alasan sangat berkurang. Dalam konseling kognitif, subjek diajarkan untuk selalu memaknai secara positif hal-hal yang terjadi dalam hidupnya. Subjek mampu mengalihkan keluhan-keluhan terkait trauma masa lalu dan persepsi tentang lingkungan menjadi pengingat untuknya agar lebih fokus pada tujuan hidup yaitu menjadi orang yang lebih mandiri dan menjadi contoh yang baik bagi kedua adik perempuannya.

Tugas rumah yang diberikan kepada subjek untuk melatih kemampuan sosial membuat subjek menemukan makna baru dan mematahkan asumsi nya selama ini. Dimulai dari 


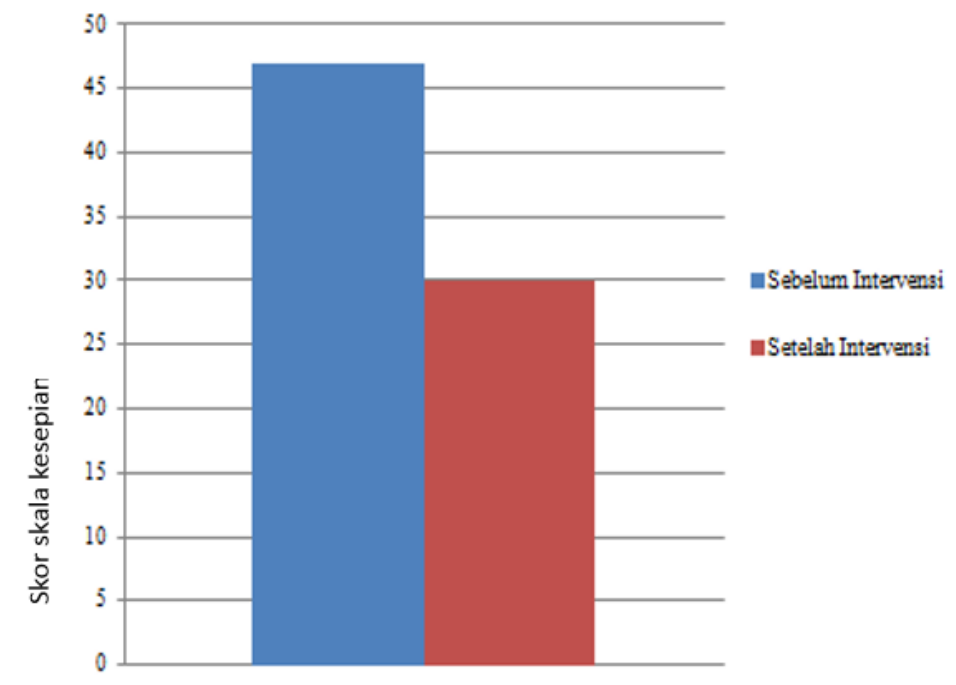

Gambar 1. Perubahan yang dialami subjek ditunjukkan dengan perbedaan hasil skala UCLA loneliness scale.

keberanian subjek menyapa teman kosnya, dilanjutkan dengan menghubungi teman subjek untuk mengajaknya bertemu hingga berani untuk pergi keluar kota dan menemui temannya yang tinggal disana. Subjek merasakan insight yang membuatnya terkejut bahwa selama ini tidak ada yang berubah dari penilaian teman terhadapnya. Lebih luas lagi, subjek mematahkan asumsi bahwa orang lain tidak menyukainya adalah tidak benar.

Peningkatan kemampuan sosial menyebabkan subjek menjadi lebih berani untuk menghubungi teman-teman lamanya untuk bertemu. Hal ini berpengaruh pada tingkat kesepian yang dirasakannya yang kemudian berangsur menurun. Kegiatan konseling efektif pada subjek karena berfokus pada perubahan pemikiran negatif ke pemikiran positif. Pendampingan terhadap individu yang memiliki masalah dengan lingkungan sangat dibutuhkan, sesuai dengan pernyataan Kemala (2017) yang menyatakan bahwa konselor perlu disediakan di sarana pendidikan untuk mengurangi masalah kesepian yang rawan muncul di usia remaja hingga dewasa awal. Mcwhlrter (1990) mengungkapkan terdapat beberapa strategi dalam menanggulangi masalah kesepian. Salah satunya adalah dengan konseling yang memberikan latihan kemampuan sosial dan dukungan sosial.

\section{Simpulan}

Konseling dengan pendekatan kognitif, mampu mengubah pemikiran negatif pada suatu kejadian menjadi pemikiran yang lebih positif. Hal ini bertujuan untuk mengurangi dan mencegah dampak psikologis yang mungkin akan dialami subjek. Pemikiran negatif subjek adalah dirinya tidak lagi diprioritaskan semenjak sahabatnya memiliki pacar, subjek merasa "salah" karena tidak memiliki pacar setelah ditertawakan oleh sahabatnya dan menarik diri dari lingkungan setelah dibully secara verbal. Asumsi-asumsi negatif tersebut membuat subjek menghindari interaksi sosial, terlebih kepada lingkungan baru. Subjek diberikan beberapa pemahaman dan diminta untuk merubah pemaknaan terhadap kejadian tersebut, dan lebih fokus pada tujuannya yaitu menjadi seorang yang mandiri serta menjadi kakak yang baik untuk kedua adik perempuannya. Subjek memiliki insight yang lebih baik dan mampu mencoba membangun interaksi dengan lingkungan sosialnya.

\section{Referensi}

Kemala, I. N. (2017). Loneliness in school: School counsellor's perspective about what, why and how. IJAEDU-International E-Journal of Advances in Education, vol. 3(9). 
Lou, L., Yan, Z., Nickerson, A., \& McMorriss, R. (2012). An examination of the reciprocal relationship of loneliness and facebook use among first-year college students. Journal Educational Computing Research, $46(1), 105-117$.

Mcwhlrter, B. T. (1990). Loneliness: A review of current literature, with implications for counseling and research. Journal of Counseling \& Development, 68, 65-70.

Maes, M. (2016). Loneliness in adolescence: types of loneliness, measurement, and a meta-analytic perspective on group differences. Faculteit Psychologie En Pedagogische Wetenschappen.

Smith, A. (2012). Innovative applications of logotherapy for military-related PTSD. ACA Conference.

Tiikkainen, P., \& Heikkinen, R.-L. (2005). Associations between loneliness, depressive symptoms and perceived togetherness in older people. Aging \& Mental Health, vol.9(6). 